\title{
PERLINDUNGAN HUKUM NASABAH BANK DALAM HAL TERJADINYA KESALAHAN SISTEM YANG MENGAKIBATKAN PERUBAHAN SALDO NASABAH
}

\author{
Rani Apriani ${ }^{1}$, Grasia Kurniawati ${ }^{2}$, Devi Siti Hamzah Marpaung ${ }^{3}$ \\ Fakultas Hukum Universitas Singaperbangsa Karawang \\ rani88_fhunsika@yahoo.com ${ }^{1}$, grasiakurniati@gmail.com ${ }^{2}$, \\ devishm89@gmail.com ${ }^{3}$ \\ DOI : https://doi.org/10.29313/shjih.v18i2.6245
}

\begin{abstract}
Abstrak
Lembaga perbankan memiliki kontribusi yang cukup dominan dalam menjaga keberlangsungan roda perekonomian, hal ini tidak luput dari peranan setiap nasabah selaku konsumen produk dan jasa bank sangat besar. Prinsip kehati-hatian wajib dijalankan oleh Bank tidak hanya karena dihubungkan dengan kewajiban Bank untuk tidak merugikan kepentingan nasabah yang mempercayakan dananya kepada Bank, tetapi juga karena kedudukan Bank yang istimewa dalam masyarakat. Penelitian ini menggunakan pendekatan yuridis normatif yang bersifat deskriptif analitis dengan teori-teori hukum dan asas-asas hukum melalui peraturan perundang-undangan yang berlaku dan diperkuat dengan studi kepustakaan dan studi lapangan. Berdasarkan hasil dari penelitian ini, Perlindungan hukum terhadap nasabah bank dalam hal terjadinya kesalahan sistem yang mengakibatkan pertambahan saldo nasabah adalah dengan perlindungan represif maupun prefentif. Perlindungan hukum preventif diberikan oleh pemerintah dalam bentuk pencegahan terjadinya pelanggaran. Hal ini diterapkan dalam pembentukan peraturan perundangundangan, pembinaan, dan pengawasan.
\end{abstract}

Kata Kunci: Perlindungan Hukum, Bank, Kesalahan Sistem, Perubahan, Saldo

\begin{abstract}
Banking institutions have a quite dominant contribution in maintaining the sustainability of the economy, this cannot be separated from the role of each customer as a consumer of bank products and services is very large. The precautionary principle must be carried out by the Bank not only because it is connected with the Bank's obligation not to harm the interests of customers who entrust their funds to the Bank, but also because of the Bank's privileged position in the community. This research is analytical descriptive using the normative juridical approach method associated with legal theories and legal principles through applicable laws and regulations and strengthened with literature studies and field studies. Based on the results of this study, legal protection for bank customers in the event of a system error that results in an increase in customer balance is repressive or prefentive protection. Preventive legal protection is provided by the government in the form of preventing violations. This is applied in the formation of laws and regulations, guidance and supervision..
\end{abstract}


Keywords: Legal Protection, Bank, System Error, Change, Balance.

\section{A. PENDAHULUAN}

Pembangunan nasional yang terdapat di Indonesia merupakan proses modernisasi yang telah membawa dampak positif dan negatif bagi kehidupan manusia. Perkembangan jaman yang semakin pesat sebagai akibat dari pembangunan yang ada banyak memberikan pengaruh dalam kemajuan budaya dan ilmu pengetahuan dan teknologi yang menimbulkan permasalahan yang multi kompleks, sehingga dalam rangka mewujudkan pembangunan yang berkesinambungan untuk terwujudnya masyarakat yang adil dan makmur berdasarkan Pancasila dan UUD 1945 diperlukan suatu peran serta baik dari sektor pemerintah maupun swasta yang senantiasa memperhatikan keserasian, keselarasan, dan kesinambungan berbagai unsur pembangunan di bidang ekonomi dan pembangunan. ${ }^{1}$

Peran serta dari lembaga keuangan merupakan salah satu sarana untuk mewujudkan pembangunan tersebut, yaitu dalam hal mengatur tatanan sistem ekonomi yang menunjang pelaksanaan tujuan pembangunan nasional. Lembaga keuangan pada dasarnya mempunyai peran yang sangat strategis dalam mengembangkan perekonomian suatu bangsa. Tumbuhnya perkembangan lembaga keuangan secara baik dansehat akan mampu mendorong perkembangan ekonomi bangsa. Lembaga keuangan tersebut dapat berbentuk Lembaga Keuangan Bank dan Lembaga Keuangan Bukan Bank.

Peran yang strategis tersebut terutama disebabkan oleh fungsi utama bank sebagai suatu wadah yang dapat menghimpun dan menyalurkan dana masyarakat secara efektif dan efisien, yang menunjang pelaksanaan pembangunan nasional dalam rangka meningkatkan pemerataan pembangunan dan hasil-hasilnya, pertumbuhan ekonomi dan stabilitas nasional ke arah peningkatan taraf hidup rakyat banyak. Di Indonesia masalah yang terkait

\footnotetext{
${ }^{1}$ Adrian Sutedi, Hukum Perbankan, Sinar Grafika, Jakarta, 2015, hlm 15
} 
dengan bank diatur dalam Undang-Undang Nomor 10 Tahun 1998 tentang Perubahan Undang-Undang Nomor 7 Tahun 1992 tentang Perbankan. Keberadaan lembaga perbankan saat ini memiliki kontribusi yang cukup dominan dalam menjaga keberlangsungan roda perekonomian. ${ }^{2}$

Kemajuan usaha perbankan tersebut tentunya tidak luput dari peranan nasabah selaku konsumen produk dan jasa bank sangat besar. Hubungan ini sangat baik dan saling menguntungkan antara pihak bank dan nasabah, dengan demikian semakin banyak nasabah yang percaya terhadap bank, maka semakin banyak dana yang dapat dihimpun dari masyarakat. Pemerintah melalui otoritas keuangan dan perbankan, dalam hal ini Bank Indonesia berwenang menetapkan aturan dan bertanggung jawab melakukan pengawasan terhadap jalannya usaha dan aktivitas perbankan. Oleh karenanya, kebijakan pemerintah disektor perbankan harus diarahkan pada upaya mewujudkan perbankan yang sehat, kuat, dan kokoh. Pemerintah telah cukup memberikan perhatian pada penyempurnaan peraturan-peraturan hukum di bidang perbankan. Mulai dari undang-undang hingga peraturan yang bersifat teknis sudah cukup tersedia. Peraturan yang berhubungan dengan prinsip kehati-hatian (prudent banking principle) sudah sangat memadai. Namun demikian kelengkapan peraturan saja tidaklah cukup untuk dijadikan ukuran bahwa perbankan nasional lepas dari segala permasalahan. Prinsip kehatihatian terdapat dalam Pasal 2 dan Pasal 29 UU No. 10 Tahun 1998 tentang Perbankan. ${ }^{3}$ Prinsip kehati-hatian adalah suatu asas atau prinsip yang menyatakan bahwa dalam menjalankan fungsi dan kegiatan usahanya, bank wajib bersikap hati-hati (prudent) dalam rangka melindungi dana masyarakat yang dipercayakan kepadanya. ${ }^{4}$ Asas kehatihatian menyatakan bahwa bank menjalankan fungsi dan kegiatan usahanya

\footnotetext{
${ }^{2}$ Etty Mulyati, Kredit Perbankan, Refika Aditama, 2017, hlm 93

${ }^{3}$ Sentosa Sembiring, Hukum Perbankan edisi Revisi, Bandung: Mandar Maju, 2012, hlm. 313

${ }^{4}$ Rachmadi Usman, Aspek-Aspek Hukum Perbankan di Indonesia, Jakarta: Gramedia Pustaka Utama, 2001. hlm. 18
} 
wajib menerapkan prinsip kehati-hatian dalam rangka melindungi dana masyarakat kepadanya. Tujuan lebih luas dari prinsip kehati-hatian adalah untuk menjaga keamanan, kesehatan, dan kestabilan system perbankan. ${ }^{5}$ Dengan diberlakukannya prinsip kehati-hatian diharapkan kadar kepercayaan terhadap perbankan tetap tinggi, sehingga masyarakat bersedia dan tidak raguragu menyimpan dananya di Bank.

Perbankan sebagai lembaga intermediasi keuangan (financial intermediary institution) memegang peranan penting dalam proses pembangunan nasional. Kegiatan usaha utama bank berupa menarik dana langsung dari masyarakat dalam bentuk simpanan dan menyalurkannya kembali kepada masyarakat dalam bentuk kredit dan/atau pembiayaan membuatnya sarat akan pengaturan baik melalui peraturan perundang-undangan di bidang perbankan sendiri maupun perundang-undangan lain yang terkait. ${ }^{6}$ Masingmasing bank mewujudkannya prinsip kehati-hatian dalam bentuk Ketentuan Standar Operasional Prosedur (SOP), bentuk perwujudan prinsip kehati-hatian pada masing-masing bank akan berbeda karena tidak adanya ukuran apa yang dimaksud prinsip kehati-hatian sehingga hanya berdasar dengan kebiasaan yang tetap berakar para peraturan perundangundangan yang berlaku.

Prinsip kehati-hatian itu harus dijalankan oleh Bank tidak hanya karena dihubungkan dengan kewajiban Bank untuk tidak merugikan kepentingan nasabah yang mempercayakan dananya kepada Bank, tetapi juga karena kedudukan Bank yang istimewa dalam masyarakat yaitu sebagai bagian dari sistem moneter yang menyangkut kepentingan semua anggota masyarakat yang bukan hanya nasabah penyimpan dana dari Bank itu saja. Tidak mudah bagi bank untuk selalu memberikan pelayanan yang memuaskan untuk nasabahnya,

\footnotetext{
${ }^{5}$ Permadi Gandapraja, Dasar dan Prinsip Pengawasan Bank, Jakarta: PT. Gramedia Pustaka Utama, 2004, hlm. 22.

${ }^{6}$ Rani Apriani, Perlindungan Hukum Terhadap Konsumen Pengguna Jasa Perbankan di Indonesia, Jurnal Ilmiah Hukum DE'JURE: Kajian Ilmiah Hukum, 2017, hlm 2.
} 
karena dalam setiap pelayanannya, bank tidak secara keseluruhan melakukan pelayanan tanpa kesalahan. Banyak sekali faktor yang mempengaruhi hal tersebut, misalnya kesalahan dari sumber daya manusia, kesalahan produk, maupun kesalahan-kesalahan yang bersifat non-teknis. Salah satu akibat dari kesalahan system yang terjadi adalah pertambahan saldo pada rekening nasabah.

Peneliti menemukan kasus mengenai adanya pemblokiran rekening nasabah yang dilakukan oleh pihak Bank tanpa sepengetahuan nasabah. Hal ini dialami oleh nasabah yang berada di daerah Karawang. Rekening nasabah tersebut secara tiba-tiba tidak dapat dipergunakan. Kejadian tersebut bermula ketika terjadi kasus perubahan saldo yang di alami oleh beberapa nasabah yang ada di daerah Karawang. Terdapat beberapa rekening yang mengalami penambahan saldo dan terdapat pula beberapa rekening yang mengalami pengurangan saldo pada tabungannya. Nasabah yang tidak mengetahui kejadian tersebut tetap mempergunakan rekening tersebut seperti biasa, baik melakukan transaksi debit maupun penarikan tunai. Namun secara mendadak rekening nasabah tersebut tidak dapat digunakan. Hal ini terjadi pembokiran rekening sepihak yang dilakukan Bank tanpa pemberitahuan sama sekali sehingga nasabah tidak dapat menggunakan dana yang terdapat di rekeningnya untuk memenuhi kebutuhan hidup sehari-hari. Berdasarkan kasus ini dapat dilihat bahwa terjadi pelanggaran terhadap fungsi perbankan, seperti yang kita ketahui Bank merupakan tempat masyarakat menyimpan dananya dilandasi oleh kepercayaan bahwa uangnya akan dapat diperoleh kembali pada waktunya dan disertai dengan bunga.

Berdasarkan permasalahan di atas persoalan yang akan dibahas dalam artikel ini adalah Bagaimana perlindungan hukum terhadap nasabah Bank dalam hal terjadinya kesalahan sistem yang mengakibatkan perubahan saldo nasabah? 


\section{B. METODE PENELITIAN}

Penelitian ini bersifat deskriptif analitis dengan menggunakan metode pendekatan yuridis normatif dikaitkan dengan teori-teori hukum dan asas-asas hukum melalui peraturan perundang-undangan yang berlaku dan diperkuat dengan studi kepustakaan dan studi lapangan. Serta pengumpulan data-data primer dan sekunder yang berkaitan dengan permasalahan yang diteliti.

\section{PEMBAHASAN}

\section{Tanggung Jawab Bank Sebagai Pelaku Usaha}

Hukum sebagai suatu aturan yang berfungsi untuk mengatur kegiatan social dan ketertiban masyarakat, maka hukum tersebut tidak dapat bekerja sendiri, akan tetapi harus senantiasa merespons terhadap hal - hal yang berkembang di lingkungannya. Hukum dalam menjalankan fungsinya sebagai pengatur kehidupan bersama dalam bermasyarakat, hukum harus menjalani suatu proses yang panjang dan melibatkan berbagai aktifitas dengan kualitas yang berbeda-beda. Pada garis besarnya aktifitas tersebut berupa pembuatan hukum dan penegak hukum. Hukum dalam pengertian disini bukanlah hukum dalam pengertian luas, tetapi hukum dalam pengertian positif yaitu peraturan tertulis atau perundang-undangan yang berlaku di suatu tempat, dalam hal ini di Indonesia. Faktor lainnya yakni masyarakat sebagai objek dan subjek dari penegakan hukum. Apabila upaya penegakan hukum tidak mendapat respon dari para pihak dalam dunia Perbankan maka sangat mungkin Undang-Undang akan hanya merupakan pasal-pasal yang tidur dan tidak bisa mencapai tujuannya.

Bank berasal dari bahasa Italia "banca" yang berarti bence yaitu suatu bangku tempat duduk. Sebab, pada zaman pertengahan, pihak banker Italia memberikan pinjaman-pinjaman melakukan usahanya tersebut dengan duduk 
di banku-bangku di halaman pasar. ${ }^{7}$ Perbankan mempunyai fungsi utama sebagai intermediasi, yaitu penghimpunan dana dari masyarakat dan menyalurkannya secara efektif dan efisien pada sector-sektor rill untuk menggerakkan pembangunan dan stebilitas perekonomian sebuah Negara. ${ }^{8}$ Berdasarkan dengan ketentuan Pasal 2 Undang-Undang Perbankan, menyebutkan bahwa Perbankan Indonesia dalam melakukan usahanya berasaskan demokrasi ekonomi dengan menggunakan prinsip kehati-hatian. Fungsi utama Perbankan Indonesia menurut Pasal 3 Undang-Undang Perbankan adalah sebagai penghimpun dan penyalur dana masyarakat. Hal ini berarti bahwa perbankan dituntut peranannya yang lebih aktif dalam menggali dana dari masyarakat dalam rangka pembangunan nasional.

Tujuan perbankan Indonesia menurut ketentuan Pasal 4 UndangUndang Perbankan adalah menunjang pelaksanaan pembangunan nasional dalam rangka meningkatkan pemerataan, pertumbuhan ekonomi, dan stabilitas nasional ke arah peningkatan kesejahteraan rakyat banyak. Dengan memperhatikan prinsip kehati-hatian yang harus dilaksanakan oleh perbankan , maka diharapkan perbankan Indonesia dalam melaksanakan usahanya akan melindungi kepentingan masyarakat penyimpan dana khususnya serta menunjang kegiatan ekonomi pada umumnya bahkan lembaga perbankan diharapkan dan dituntut untuk mampu menciptakan stabilitas nasional dalam arti yang seluas-luasnya.

Prinsip kehati-hatian dalam perbankan adalah suatu asas atau prinsip yang menyatakan bahwa bank dalam menjalankan fungsi dan kegiatan usahanya wajib menerapkan prinsip kehati-hatian dalam rangka melindungi dana masyarakat yang dipercayakan kepada bank tersebut. Pihak bank diharapkan selalu berhati-hati dalam menjalankan kegiatan usahanya, bank

${ }^{7}$ A. Abdurrachman, Ensiklopedia Ekonomi Keuangan Perdagangan, Jakarta: Pradya Paramita, 1991, hlm. 80.

${ }^{8}$ Rani Apriani dan Hartanto, Hukum Perbankan dan Surat Berharga, Yogyakarta: deepublish, 2019, hlm. 1. 
harus selalu konsisten untuk melaksanakan peraturan perundang-undangan di bidang perbankan berdasarkan profesionalisme dan itikad baik. ${ }^{9}$ Akan tetapi, terkadang terjadi pelanggaran terhadap prinsip kehati-hatian yang diterapkan dikarenakan adanya tindakan yang tidak sesuai dengan peraturan perundangundangan.

Dalam hal terjadinya suatu kesalahan sistem yang mengakibatkan perubahan saldo nasabah di lembaga perbankan dimana selanjutnya dilakukan pemblokiran sepihak oleh Bank yang tidak diketahui oleh nasabah, maka pihak yang bertanggung jawab adalah bank yang berkedudukan sebagai penyedia jasa layanan, yang dalam hal ini bank disebut juga sebagai pelaku usaha. Tanggung jawab setiap pelaku usaha adalah sebagaimana tercantum dalam Pasal 19 Undang-Undang Nomor 8 Tahun 1999 tentang Perlindungan Konsumen, yaitu:

1. Pelaku usaha mempunyai tanggung jawab untuk memberikan ganti rugi atas kerusakan, pencemaran, dan/atau kerugian konsumen akibat mengkonsumsi barang dan/atau jasa yang dihasilkan atau diperdagangkan.

2. Ganti rugi sebagaimana dimaksud pada ayat (1) dapat berupa pengembalian uang atau penggantian barang dan/atau jasa yang sejenis atau setara nilainya, atau perawatan kesehatan dan/atau pemberian santunan yang sesuai dengan ketentuan peraturan perundang-undangan yang berlaku.

3. Pemberian ganti rugi dilaksanakan dalam tenggat waktu 7 (tujuh) hari setelah tanggal transaksi.

4. Pemberian ganti rugi sebagaimana dimaksud pada ayat (1) dan ayat (2) tidak menghapuskan kemungkinan adanya tuntutan pidana berdasarkan pembuktian lebih lanjut mengenai adanya unsur kesalahan.

5. Ketentuan sebagaimana dimaksud pada ayat (1) dan ayat (2) tidak berlaku apabila pelaku usaha dapat membuktikan bahwa kesalahan tersebut kesalahan konsumen.

${ }^{9}$ Hermansyah, Hukum Perbankan Nasional Indonesia, Jakarta: Kencana Prenada Media Group, 2013. hlm. 7 
Secara umum, tuntutan ganti kerugian yang dialami oleh konsumen sebagai akibat penggunaan produk, baik yang berupa kerugian materi, fisik maupun jiiwa, dapat didasarkan pada beberapa ketentuan, secara garis besar ada dua kategori, yaitu tuntutan ganti kerugian berdasarkan wanprestasi dan tuntutan ganti kerugian berdasarkan perbuatan melawan hukum. ${ }^{10}$ Bentuk pertanggungjawaban bank salah satunya dalam kasus bila terjadi kerugian yang dialami dalam hal terjadi kesalahan sistem yang mengakibatkan pertambahan saldo nasabah dimana selanjutnya dilakukan pemblokiran sepihak oleh Bank, diwujudkan dengan mengembalikan dana nasabah ke dalam rekening nasabah sejumlah yang besarnya sama dengan kerugian tersebut. Hal ini mewujudkan bahwa bank telah memenuhi kewajibannya sebagai pelaku usaha untuk menyelesaikan masalah, namun bukan sebagai bentuk pemberian ganti rugi sebagaimana Pasal 7 huruf f Undang-Undang Nomor 8 Tahun 1999 tentang Perlindungan Konsumen.

Lembaga perbankan adalah lembaga yang mengandalkan kepercayaan masyarakat. Dengan demikian, guna tetap mengekalkan kepercayaan masyarakat terhadap bank, pemerintah harus berusaha melindungi masyarakat dari tindakan lembaga ataupun oknum pegawai bank yang tidak bertanggung jawab dan merusak sendi kepercayaan masyarakat. Apabila suatu saat terjadi merosotnya kepercayaan masyarakat terhadap lembaga perbankan, hal tersebut merupakan suatu bencana bagi ekonomi negara secara keseluruhan dan keadaan tersebut sangat sulit untuk dipulihkan kembali. ${ }^{11}$ Melihat begitu besarnya risiko yang dapat terjadi apabila kepercayaan masyarakat terhadap lembaga perbankan merosot, tidak berlebihan jika usaha perlindungan konsumen jasa perbankan mendapat perhatian yang khusus. Dalam rangka usaha melindungi konsumen

\footnotetext{
${ }^{10}$ Ahmad Miru dan Sutarman Yodo, Hukum Perlindungan Konsumen, Jakarta, Raja Grafindo Persada, 2004, hlm. 127.

${ }^{11}$ Muhammad Djumhana, Hukum Perbankan di Indonesia, PT. Citra Aditya Bakti,Bandung,2012, hlm. 303
} 
secara umum sekarang ini telah ada Undang-Undangnya, yaitu Undang-Undang Nomor 8 Tahun 1999 tentang Perlindungan Konsumen.

Menyangkut usaha untuk melindungi konsumen sebenarnya tidak bergantung pada penerapan hukum perdata semata sebagaimana diharapkan melalui sanksi dan mekanisme gugatan ganti rugi. ${ }^{12}$ Ketentuan hukum lainnya, seperti hukum pidana ataupun hukum administrasi negara juga memuat ketentuan aturan yang dapat melindungi konsumen, contohnya yaitu mengenai mekanisme perizinan dan pengawasan yang diperketat. Kondisi saat ini bahkan perlindungan konsumen telah mendapatkan perhatian yang lebih serius dengan ditetapkannya peraturan perundang-undangan yang mengatur untuk itu, yakni Undang-Undang Nomor 8 Tahun 1999 tentang Perlindungan Konsumen. Namun, tetap diperlukan suatu kehati-hatian dalam menentukan siapa yang bertanggung jawab atas kelalaian atau kesalahan yang telah terjadi dalam pengelolaan atau pengurusan bank sehingga terjadi suatu kerugian yang dialami oleh para nasabah. Langkah nyata dari Bank Indonesia dalam perlindungan konsumen saat ini sudah semakin terlihat, di antaranya,menempatkan perlindungan konsumen sebagai salah satu pilar perbankan nasional. Menyangkut pengaturan pun sudah terlihat dengan diterbitkannya beberapa peraturan yang secara fokus untuk melindungi konsumen, diantaranya dengan membuat regulasi maupun terbentuknya Otoritas Jasa Keuangan sebagai salah satu lembaga yang melakukan pengawasan terhadap berjalannya perbankan di Indonesia.

\section{Perlindungan Hukum Nasabah Bank Dalam Hal Terjadinya Kesalahan Sistem Yang Mengakibatkan Perubahan Saldo Nasabah}

Membicarakan perlindungan hukum terhadap nasabah kita tidak dapat memisahkan diri dengan Undang-Undang Nomor 8 Tahun 1999 tentang Perlindungan Konsumen, karena pada dasarnya Undang-Undang inilah yang dijadikan bagi perlindungan konsumen termasuk halnya nasabah secara umum. Masalah perlindungan hukum bagi konsumen perbankan merupakan suatu hal

12 Ibid, hlm 304. 
yang sangat dilematis, sehingga sampai saat ini masalah perlindungan hukum bagi konsumen belum mendapat tempat yang baik dalam sistem perbankan nasional. ${ }^{13}$

Perlindungan konsumen dipandang secara material maupun formal makin terasa sangat penting, mengingat makin lajunya ilmu pengetahuan dan teknologi yang merupakan motor penggerak bagi produktivitas dan efisiensi produsen atas barang atau jasa yang dihasilkannya dalam rangka mencapai sasaran usaha. Dalam rangka mengejar dan mencapai kedua hal tersebut, akhirnya baik langsung maupun tidak langsung, konsumenlah yang pada umumnya akan merasakan dampaknya. Dengan demikian, upaya-upaya dalam memberikan perlindungan terhadap kepentingan konsumen terutama konsumen di Indonesia merupakan suatu hal yang penting untuk segera dicari solusinya, terlebih pada era perdagangan bebas saat ini. ${ }^{14}$ Bank Indonesia sebagai pelaksana otoritas moneter mempunyai peranan yang besar dalam usaha melindungi, dan menjamin agar nasabah tidak mengalami kerugian akibat tindakan bank yang salah. Hal-hal yang menyangkut dengan usaha perlindungan nasabah diantaranya berupa laporan dan data-data yang merupakan bahan informasi. Perlindungan hukum bagi rakyat meliputi dua hal yaitu perlindungan hukum preventif dan represif. Perlindungan hukum preventif diberikan oleh pemerintah dalam bentuk pencegahan terjadinya pelanggaran.Hal ini diterapkan dalam pembentukan peraturan perundang-undangan, pembinaan, dan pengawasan.

Perlindungan hukum represif merupakan perllindungan akhir berupa penindakan dan pemberian sanksi seperti denda, penjara dan hukuman tambahan yang diberikan apabila sudah terjadi sengketa atau telah dilakukan suatu

\footnotetext{
${ }^{13}$ Wulanmas A. P. G. Frederik, Buku Ajar Hukum Perbankan, Yogyakarta, Genta Press, 2012, hlm. 139.

${ }^{14}$ Cerlina Tri Siwi Kristiyanti, Hukum Perlindungan Konsumen, Malang, Sinar Grafika, 2014, hlm. 5
} 
pelanggaran terhadap peraturan tertentu. ${ }^{15}$ Jika dilihat dari Pasal 4 huruf a Undang-Undang Nomor 8 Tahun 1999 tentang Perlindungan Konsumen, bank seharusnya memberikan pelayanan yang terbaik dalam pelayanan perbankan yang ditawarkannya, dan nasabah sebagai konsumen pengguna jasanya berhak mendapat fasilitas terbaik, terutama berkaitan dengan dana nasabah. Namun pada kasus ini, bank tidak memberikan kenyamanan dan keamanan bagi nasabah dalam menggunakan dikarenakan terjadi kesalahan sistem yang menyebabkan pertambahan saldo nasabah dimana hal tersebut ditindaklanjutin dengan pemblokiran sepihak sehingga nasabah tidak dapat menggunakan dana yang ada di dalam rekeningnya. Di dalam kasus yang diangkat peneliti, Bank tidak memberikan kenyamanan dan keamanan bagi nasabah dalam menggunakan jasa perbankannya. Hal ini terbukti dengan adanya nasabah yang merasa dirugikan akibat kesalahan dari sistem Bank yang mengakibatkan bertambahnya saldo nasabah serta pemblokiran sepihak yang dilakukan oleh bank hingga berakibat juga nasabah mengalami kerugian akibat hal-hal tersebut di atas. Dengan demikian produk bank tersebut tidak memberikan kenyamanan dan keamanan bagi nasabah pengguna jasa perbankan.

Perlindungan represif dilakukan dengan adanya pembentukan ketentuanketentuan yang dapat melindungi nasabah apabila terjadi kasus sebagaimana diangkat oleh penulis, seperti:

1. Pasal 2 Jo Pasal 49 ayat (2), Pasal 52 Undang-Undang Nomor 10 Tahun 1998 Tentang Perubahan Atas Undang-Undang Nomor 7 Tahun 1992 Tentang Perbankan;

2. Pasal 4 jo. Pasal 7 Jo. Pasal 84 Peraturan Pemerintah Nomor 82 Tahun 2012 Tentang Penyelenggaraan Sistem Dan Transaksi Elektronik;

3. Pasal 2, Pasal 4, Pasal 7, Undang-Undang Nomor 8 Tahun 1999 tentang Perlindungan Konsumen;

${ }^{15}$ Sri Sumantri, Bunga Rampai Hukum Tata Negara Indonesia, Bandung, Alumni,1992, hlm. 15 
4. Pasal 2, Pasal 5, Pasal 6, Pasal 29, Pasal 32, Pasal 34, Pasal 38 Peraturan

Otoritas Jasa Keuangan Nomor: 1/POJK.07/2013 Tentang Perlindungan

Konsumen Sektor Jasa Keuangan;

5. Pasal 1365 Kitab Undang-Undang Hukum Perdata.

Kesalahan dari sistem bank yang mengakibatkan kerugian pada nasabah merupakan hal yang terus terjadi. Hal ini membuktikan bahwa perlindungan preventif juga diperlukan dalam perlindungan hukum bagi nasabah yang mengalami kerugian akibat kesalahan dari sistem bank dapat dilakukan dengan pembentukan peraturan perundang-undangan yang berkaitan dengan perlindungan hukum bagi nasabah yang mengalami kerugian akibat kesalahan sistem bank adalah Undang-Undang Nomor 10 Tahun 1998 tentang Perubahan Atas Undang-Undang Nomor 7 Tahun 1992 tentang Perbankan; UndangUndang Nomor 8 Tahun 1999 tentang Perlindungan Konsumen; UndangUndang Nomor 30 Tahun 1999 tentang Arbitrase dan Alterntif; Undang-Undang Nomor 11 Tahun 2008 tentang Informasi dan Transaksi Elektronik; UndangUndang Nomor 21 Tahun 2011 tentang Otoritas Jasa Keuangan.

Berbeda dengan perlindungan preventif, perlindungan hukum represif merupakan perlindungan akhir berupa sanksi seperti denda, penjara, dan hukuman tambahan apabila sudah terjadi sengketa atau suatu pelanggaran seperti pelanggaran terhadap hak konsumen atas pemberian informasi yang benar. Terhadap pelanggaran tersebut, dibutuhkan adanya upaya penyelesaian sengketa konsumen atau nasabah untuk membuktikan adanya unsur kesalahan pelaku usaha atau bank atas pelanggaran hak-hak konsumen. Setiap pelanggaran yang terbukti dilakukan oleh pelaku usaha, maka kepadanya akan diberikan sanksi.

\section{PENUTUP}

1. Bank sebagai pelaku usaha secara yuridis dapat dimintai pertanggungjawaban hukum berupa pengembalian uang atau penggantian barang dan/atau jasa yang sejenis atau setara nilainya. 
Pertanggungjawaban ini tidak menghapuskan kemungkinan adanya tuntutan pidana berdasarkan pembuktian lebih lanjut mengenai adanya unsur kesalahan.

2. Perlindungan hukum terhadap nasabah bank dalam hal terjadinya kesalahan sistem yang mengakibatkan perubahan saldo nasabah adalah dengan menggunakan perlindungan represif maupun preventif. Perlindungan hukum preventif yang diberikan oleh pemerintah kepada nasabah perbankan dalam bentuk pencegahan terjadinya pelanggaran. Hal ini diterapkan melalui pembentukan peraturan perundangundangan, pembinaan, dan pengawasan. Perlindungan hukum represif yang dapat diberikan kepada nasabah perbankan yaitu pemenuhan hak, pemberian kompensasi sampai pengembalian kerugian yang diderita nasabah bank sesuai peraturan perundang-undangan yang berlaku. 


\section{DAFTAR PUSTAKA}

\section{A. Buku}

A.Abdurrachman, Ensiklopedia Ekonomi Keuangan Perdagangan, Jakarta: Pradya Paramita, 1991.

Ahmad Miru dan Sutarman Yodo, Hukum Perlindungan Konsumen, Jakarta, Raja Grafindo Persada, 2004.

Adrian Sutedi, Hukum Perbankan, Sinar Grafika, Jakarta, 2015.

Cerlina Tri Siwi Kristiyanti, Hukum Perlindungan Konsumen, Malang, Sinar Grafika, 2014.

Etty Mulyati, Kredit Perbankan, Refika Aditama, Bandung, 2017.

Hermansyah, Hukum Perbankan Nasional Indonesia, Jakarta: Kencana Prenada Media Group, 2013.

Muhammad Djumhana, Hukum Perbankan di Indonesia, PT. Citra Aditya Bakti, Bandung, 2012.

Permadi Gandapraja, Dasar dan Prinsip Pengawasan Bank, Jakarta: PT. Gramedia Pustaka Utama, 2004.

Rachmadi Usman, Aspek-Aspek Hukum Perbankan di Indonesia, Jakarta: Gramedia Pustaka Utama, 2001.

Rani Apriani, Perlindungan Hukum Terhadap Konsumen Pengguna Jasa Perbankan di Indonesia, Jurnal Ilmiah Hukum De 'Jure: Kajian Ilmiah Hukum, 2017.

Rani Apriani dan Hartanto, Hukum Perbankan dan Surat Berharga, Yogyakarta: deepublish, 2019.

Sentosa Sembiring, Hukum Perbankan edisi Revisi, Bandung: Mandar Maju, 2012.

Sri Sumantri, Bunga Rampai Hukum Tata Negara Indonesia, Bandung, Alumni,1992.

Wulanmas A. P. G. Frederik, Buku Ajar Hukum Perbankan, Yogyakarta, Genta Press, 2012. 


\section{B. Peraturan Perundang-Undangan}

Undang-Undang Dasar 1945

Kitab Undang-Undang Hukum Perdata

Undang-Undang No. 3 Tahun 2004 tentang Perubahan atas UndangUndang 23 Tahun 1999 Tentang Bank Indonesia

Undang-Undang Nomor 10 Tahun 1998 Tentang Perubahan Atas UndangUndang Nomor 7 Tahun 1992 Tentang Perbankan

Undang-Undang Nomor 8 Tahun 1999 tentang Perlindungan Konsumen

Undang-Undang No. 21 Tahun 2011 tentang Otoritas Jasa Keuangan

Peraturan Bank Indonesia No.11/25/PBI/2009 tentang Penerapan Manajemen Risiko

Peraturan Bank Indonesia No.2/19/PBI/2000 tentang Persyaratan dan Tata Cara Pemberian Perintah atau Izin Tertulis Membuka Rahasia Bank

Peraturan Otoritas Jasa Keuangan No. 01/POJK.07/2013 tentang Perlindungan Konsumen Sektor Jasa Keuangan

Peraturan Pemerintah Nomor 82 Tahun 2012 Tentang Penyelenggaraan Sistem Dan Transaksi Elektronik. 